TEKNIK, 42 (3), 2021, 325-334

\title{
Analisis Ruang Preferensi pada Rumah Tinggal untuk Orang Tua Berusia Lanjut
}

\author{
Wijayanti *, Ria Ripardi Wahyu Lestari \\ Departemen Arsitektur, Fakultas Teknik, Universitas Diponegoro \\ Jl. Prof. Soedharto, SH, Tembalang, Semarang, Indonesia 50275
}

\begin{abstract}
Abstrak
Penelitian ini terkait dengan fenomena aging in place yang menunjukkan pilihan orang tua yang berusia lanjut/ manula tetap tinggal di rumahnya. Fenomena tersebut terlihat di sebuah perumnas skala besar di wilayah pengembangan kota Semarang bagian selatan. Penghuni perumahan tersebut saat ini telah memasuki usia lebih dari 60 tahun. Hal ini menunjukkan pentingnya rumah bagi penghuni, Mereka telah menjadikan rumahnya sebagai homes seiring dengan proses menuanya. Dalam kegiatan sehari-harinya di dalam rumah, manula memiliki pandangan terhadap ruang-ruang yang sesuai dengan kebutuhan aktivitasnya. Penelitian ini bertujuan untuk mengetahui kategori ruang preferensi manula di dalam rumahnya sehingga aktivitas yang dilakukan dapat terakomodasi dengan baik. Dengan metode kualitatif, data utama yang digunakan adalah manula yang dapat mandiri dalam beraktifitas dan manula yang perlu bantuan dengan teknik observasi, wawancara, studi literatur dan dokumentasi. Dari kajian yang dilakukan, penelitian ini menghasilkan 3 kategori ruang preferensi manula yaitu : ruang personal, ruang interaksi dan ruang ibadah.
\end{abstract}

Kata kunci: kategori ruang; ruang preferensi; manula; aging in place

\begin{abstract}
[Title: Analysis of preference room in residential homes for elderly parents] This research is related to the aging in place phenomenon, which shows the choice of the elderly to stay at home. This phenomenon is seen in large-scale public housing in the southern part of the Semarang city development area. The occupants of the housing are now more than 60 years old. This shows the importance of houses for residents. They have made their houses as homes along with the aging process. In their daily activities at home, the elderly view spaces that suit their activity needs. This study aims to determine the category of the elderly preference room in the house where the activities carried out can be adequately accommodated. With qualitative methods, the primary data used are the elderly who can be independent in their activities and the elderly who need assistance. Data is taken through observation, interviews, literature studies, and documentation techniques. The studies conducted resulted in 3 categories of the elderly preference rooms: personal room, interaction room, and worship room.
\end{abstract}

Keywords: room category; preference room; elderly; aging in place

\section{Pendahuluan}

Rumah menjadi perhatian penting berkaitan dengan adanya pilihan manula untuk tetap tinggal di rumah pada masa tua dari pada tinggal ditempat baru seperti panti jompo atau rumah anak. Lingkungan tempat tinggal yang baru dan berbeda menyebabkan manula harus beradaptasi

\footnotetext{
${ }^{*}$ Penulis Korespondensi.

E-mail: wijayanti.jaft@gmail.com
}

dan menyesuaikan diri secara positif maupun negatif sehingga dapat berpengaruh terhadap kesehatan manula (Mendoko et al., 2017). Rumah tinggal bagi manula akan menjadi lebih penting lagi saat jumlah populasi manula semakin bertambah besar dikarenakan kemajuan ilmu pengetahuan dan teknologi seperti dibidang kesehatan. Pada saat ini presentase masyarakat/ orang/ manusia berusia lanjut (manula) dalam waktu hampir lima dekade (1971-2020) meningkat dua kali lipat menjadi 9,92 persen (26 juta-an). Angka ini akan diproyeksikan akan terus 


\section{TEKNIK, 42 (3), 2021, 326}

meningkat jumlahnya, pada tahun 2045 manula di Indonesia diperkirakan hampir mencapai seperlima dari seluruh penduduk Indonesia. Perhatian terhadap manula oleh pemerintah diwujudkan dengan diterbitkannya Peraturan Menteri Sosial Nomor 4 Tahun 2017 yang menjelaskan adanya perlunya kawasan ramah manula, serta Peraturan Menteri Pekerjaan Umum Nomor: 30/PRT/M/2006 yang mengarahkan perlunya tatanan fisik bangunan dan lingkungan yang memperhatikan keberadaan manula. Diharapkan kawasan dimana manula tinggal dapat merespon kebutuhan yang berbasis pada kompetensi yang dimiliki manula, baik fisik maupun nonfisik.

Rumah merupakan bangunan tempat tinggal yang berperan mendukung manula menjalankan kehidupannya. Perumnas yang menjadi lokus amatan dalam penelitian merupakan perumahan lama yang telah berumur 42 tahun. Usia penghuninya rata-rata telah mencapai 60 tahun ke atas dan mereka dikategorikan sebagai manula (Ekasari et al., 2019). Dengan kondisi yang ada, di perumahan tersebut terdapat fenomena aging in place. Fenomena ini menunjukkan adanya pilihan individu untuk tetap tinggal di rumah dan komunitasnya dengan kemandirian hingga usia tua (Wiles et al., 2012). Dalam hal ini, secara fisik rumah menjadi penting bagi manula, dan konstruksi rumah perlu diperhatikan untuk memberikan pengaruh yang baik bagi kesehatan manula (Howden-Chapman et al., 1999). Upaya perbaikan rumah secara struktural maupun pengaturan tata letak perabot serta elemen-elemen pembentuk ruang dalam konteks adapatasi rumah (home adaptation) perlu juga diperhatikan berbasis kompetensi fisik maupun non fisik manula (Wijayanti, 2018), serta makna rumah bagi manula sehingga manula tidak kehilangan orientasi terhadap rumahnya setelah dilakukan perbaikan rumah (Luciano et al., 2020). Hal ini penting terlebih bila dikaitkan dengan keberlanjutan manula dalam melakukan aktivitas keseharian, terutama bagi manula yang terkendala aktivitasnya karena memiliki keterbatasan fisik yang disebabkan adanya penyakit kronis (Omiya et al., 2016) Dalam pembahasan yang lebih luas, pentingnya rumah bagi manula juga terkait dengan lingkungan hunian manula. Lingkungan yang ramah bagi manula sangat berkontribusi terhadap terwujudnya jaringan sosial, komunitas manula yang dapat mendorong keaktivan dan pola hidup manula yang lebih berkualitas (Aung et al., 2021). Dengan demikian rumah serta lingkungan dimana manula tinggal akan memberikan pengaruh kepada keberlanjutan aktivitas keseharian serta kesehatan manula baik fisik maupun non fisik.

Berkaitan dengan rumah secara umum dan rumahrumah dimana manula tinggal, memiliki bentuk dan fungsi ruang-ruang untuk mengakomodasi aktivitas penghuninya seperti halnya duduk, istirahat, tidur, makan-minum, hubungan sosial, memasak dan lain sebagainya. Perbedaan bentuk dan fungsi ruang-ruang akan mempengaruhi tatanan serta bentuk perabot, jendela, dinding, penutup lantai dan aksesoris di setiap ruang. Hal ini berdampak pada persepsi penghuni dan menimbulkan rasa suka terhadap ruang-ruang tertentu yang ada di dalam rumah (Triyuly \& Kusuma, 2015). Kesukaan penghuni terhadap ruang ditunjukan dengan menetapkan ruang sebagai ruang pilihan untuk sering digunakan beraktivitas. Kecenderungan untuk memilih sesuatu yang lebih disukai dari pada yang lain disebut juga dengan preferensi. Preferensi merupakan bagian dari komponen pembuatan keputusan dari seorang individu (Nova, 2013). Berkaitan dengan hal tersebut setiap penghuni rumah, dari aspek tingkatan usia, akan memiliki preferensi terhadap ruang yang berbeda disesuaikan dengan kebutuhan terkait aktivitasnya. Preferensi terhadap ruang oleh manula bukan hanya karena rasa suka dari segi elemen desain, namun terdapat pertimbangan-pertimbangan yang berhubungan dengan karakteristik dan masalah penurunan kesehatan karena proses penuaan. Manula memiliki beberapa karakteristik antara lain usia, jenis kelamin, status pernikahan, living arrangement, kondisi kesehatan, sosial ekonomi (Nova, 2013).

Merujuk pada karakteristik manula tersebut di atas, perlu adanya upaya penyesuaian rumah agar dapat dihuni oleh manula dengan aman dan nyaman. Selain fisik hunian serta lingkungannya yang dapat mengakomodasi keamanan dan kenyaman fisik manula, diperlukan juga lingkungan sosial yang mendukung. Dukungan sosial dapat diperoleh manula dengan adanya model perumahan yang memungkinkan multi-famili yang tinggal bersama dalam satu kawasan perumahan dimana manula tinggal (Prosper, 2004). Hal ini menunjukkan hunian secara fisik dapat mengakomodasi baik kebutuhan fisik maupun non fisik manula yang tinggal di dalamnya.

Pembahasan ini memberikan dasar bagi pentingnya studi yang terfokus pada proses kehidupan manula di rumahnya dan hal-hal yang dapat mendukung proses kehidupan tersebut baik yang bersifat fisik dan non fisik. Namun demikian studi-studi yang terdahulu belum menyentuh ruang-ruang yang menjadi pilihan manula terkait dengan pemenuhan kebutuhan fisik sekaligus kebutuhan non fisik dalam kegiatan keseharian manula dengan latar belangan karakteristik manula.

Oleh karena itu tujuan penelitian ini adalah mengetahui kategori ruang preferensi manula yang dilatarbelakangi aktivitas keseharian serta karakteristik manula yang hasilnya nanti diharapkan dapat memberikan suatu masukan untuk perencanaan dan perancangan rumah yang ramah bagi manula.

\section{Bahan dan Metode}

Dengan menggunakan metode penelitian kualitatif, penelitian dilakukan di sebuah perumahan rakyat yang telah didiami oleh penghuninya sejak tahun 1979. Penghuninya adalah para pensiunan pegawai negri sipil 


\section{TEKNIK, 42 (3), 2021, 327}

dan ABRI/POLRI yang telah mengalami aging in place. Selama menghuni rumah dan lingkungannya, mereka telah melakukan beberapa penyesuaian rumah baik di skala rumah (mikro), lingkungan rumah (meso) dan kawasan perumahan (makro) dalam konsep adaptasi rumah (home adaptation). Penelitian ini melibatkan manula sebagai responden dan amatan penelitian terfokus pada skala mikro. Ada 7 Manula yang bersedia menjadi responden. 6 responden masih aktif melakukan aktivitas baik di rumah maupun di lingkungan sosialnya, sedangkan 1 responden tidak dapat bergerak secara aktif dan lebih banyak berdiam diri di rumah karena kondisi kesehatannya. Responden telah memasuki usia lebih dari 60 tahun. Penelitian ini diawali dengan kajian literatur yang diambil dari jurnaljurnal dan buku-buku yang relevan dengan penelitian untuk memperoleh informasi mendalam terkait dengan pengetahuan tentang manula dan karakteristinya, kegiatan ruang-ruang yang memiliki nilai penting bagi manula sehingga manula memilih ruang-ruang tertentu untuk mengakomodasi kegiatan tersebut. Pengetahuan tersebut dapat menjadi background knowledge saat dilakukan studi lapangan. Data diperoleh melalui observasi lapangan dengan melihat langsung aktivitas manula sehari-hari di rumah, wawancara dengan manula serta dokumentasi penelitian dengan cara mengambil foto-foto kegiatan dan keadaan rumah manula sehingga mengahasilkan gambaran rumah secara utuh seperti denah serta tatanan perabotnya. Dari data-data yang terkumpul dilakukan analisis dengan cara menghubungkan data satu dan lainnya hingga mendapatkan hasil dan kesimpulan yang berupa deskripsi terkait dengan kategori ruang preferensi manula.

\section{Hasil dan pembahasan}

Karakteristik Manula dan Ruang Preferensi Manula

Informan pertama merupakan manula berusia 73 tahun dan tinggal seorang diri di rumah dengan kondisi kesehatan fisik sehat tetapi kemampuan mata dalam jarak pandang berkurang, kondisi psikologis menyukai ketenangan dan sering merasa kesepian sehingga memiliki kegiatan untuk mengalihkan pikiran dengan cara merawat tanaman dan kura-kura, sedangkan kondisi sosial informan pertama adalah sering berinteraksi dengan tetangga aktif dalam perkumpulan Pepabri I (Persatuan Pensiunan ABRI/POLRI), PKK (Kelompok Ibu-ibu dalam lingkungan rumah). Rumah informan pertama terdiri dari satu lantai dengan 8 ruang yang ada didalamnya antara lain teras, ruang tamu, ruang tidur utama, ruang tidur tamu, gudang, ruang jemur, dapur, dan $\mathrm{km} / \mathrm{wc}$. (dilihat pada Gambar 1).

Dari hasil wawancara dan observasi ruang pilihan informan pertama adalah teras dan ruang tamu. Teras rumah tidak banyak perabot dan digunakan untuk meletakan tanaman hias yang merupakan hobi penghuni sembari mengobrol dengan tetangga yang berkunjung, selain itu diteras terdapat ram untuk memudahkan pergerakan dan pelengkap keselamatan manula saat membawa perabot ataupun kendaraan sedangkan di ruang tamu terdapat beberapa foto lawas yang dijadikan sebagai tempat untuk nostalgia dan ruangan sering digunakan untuk ibadah oleh informan pertama.

Informan kedua merupakan manula berusia 74 tahun tinggal bersama suami beserta anak dan cucu. Kondisi kesehatan fisik informan kedua sehat namun pada malam hari susah tidur dan kemampuan mata berkurang dalam meyesuaikan cahaya dan penyempitan jarak pandang. Kondisi psikologis informan kedua terjadi peningkatan sensivitas emosional yaitu : merenung teringat masa lalu sehingga untuk mengatasi kondisi dan mengalihkan pikiran tersebut informan kedua memiliki kegiatan bermain dengan cucu dan berolahraga ringan setiap pagi. Kondisi sosial informan kedua adalah aktif dalam kegiatan sosial, aktif dalam mengikuti perkumpulan RT, RW, PKK, aktif melakukan pengajian dirumah sendiri 2 hari sekali dan aktif melakukan olahraga senam bersama tetangga. Rumah tinggal informan kedua terdiri dari 2 lantai dengan 16 ruang. Lantai 1 terdiri dari ruang : parkiran,teras, ruang tamu, taman, ruang makan, $\mathrm{km} / \mathrm{wc}$, dapur, ruang jemur, gudang (2), ruang tidur (2) dan ruang sholat. Lantai 2 terdiri dari ruang jemur, ruang tidur ( 2) (dilihat pada Gambar 2)

Berdasarkan data diatas dan hasil wawancara maupun observasi, ruang preferensi informan kedua di rumah tinggal adalah ruang tamu dan kamar tidur informan. Alasan ruang tamu dijadikan ruang pilihan dan sering digunakan sebagai tempat kegiatan bersama tetangga seperti bermain dengan cucu, mengaji bersama, arisan, latihan kosidah dan lain-lain karena memiliki jendela cukup besar sehingga ruangan mendapatkan cahaya yang maksimal selain itu disamping ruangan terdapat taman buatan. Sedangkan kamar tidur digunakan informan menghabiskan waktu nya untuk sholat, mengaji, menonton TV, mendengarkan radio, dan beristirahat.

Informan ketiga, merupakan manula wanita berusia 65 tahun yang merupakan ibu RT dan tinggal bersama suami dan 3 orang anak. Kondisi fisik informan 3 mudah lelah dan kemampuan mata berkurang dalam meyesuaikan cahaya dan penyempitan jarak pandang. Kondisi psikologis informan 3 kadang merenungkan masa lalu sehingga untuk mengatasinya manula mengalihkan pikiran dengan karaoke, sedangkan kondisi sosial informan 3 aktif dalam kegiatan sosial, keagamaan, dan aktif mengikuti olahraga bersama manula perumnas setiap 1 minggu sekali. Rumah informan 3 terdiri dari 1 lantai dengan ruang - ruang didalamnya antara lain teras, ruang tamu, ruang tidur (2), $\mathrm{km} / \mathrm{wc}(2)$, dapur, ruang makan, ruang berkumpul/karaoke, dan teras belakang (dilihat pada Gambar 3). 
TEKNIK, 42 (3), 2021, 328

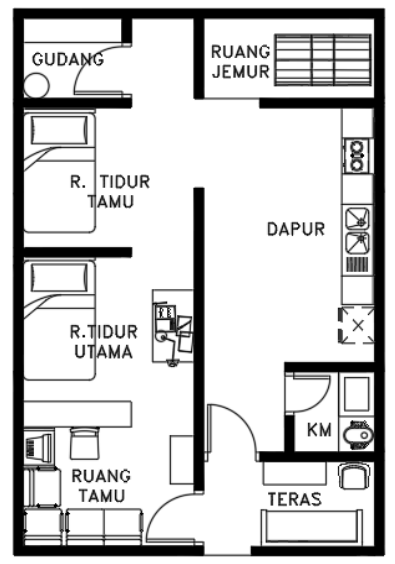

(a)

Gambar 1 (a) Denah rumah informan pertama

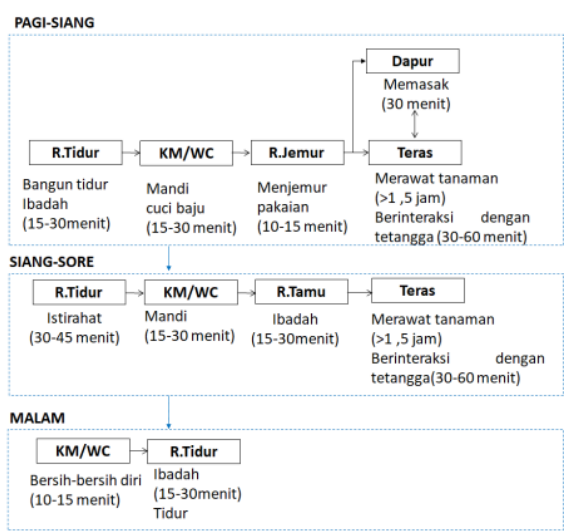

(b)

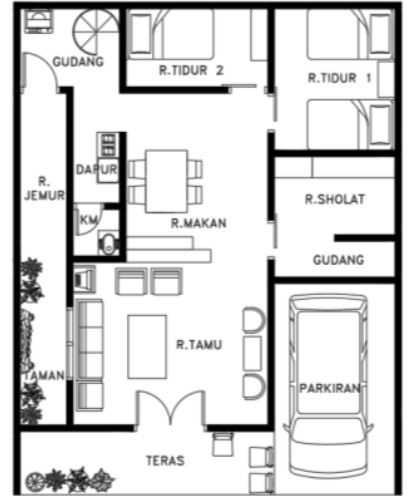

Denah Lantai 1

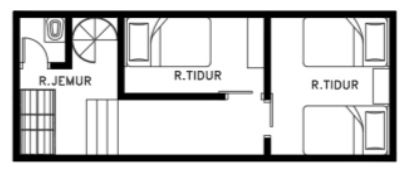

Denah Lantai 2

(a)

Gambar 2 (a) Denah rumah informan dua (lantai 1 dan 2), (b) aktivitas informan dua

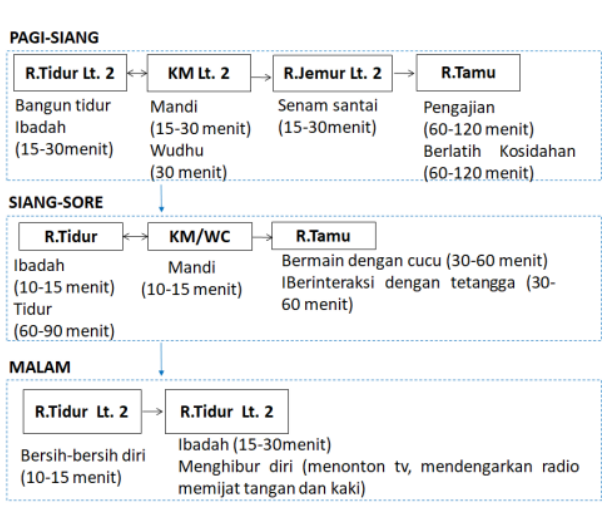

(b)
Ruang pilihan / preferensi informan 3 di rumah tinggal adalah teras belakang dan ruang berkumpul. Teras belakang merupakan area terbuka yang cukup luas dan rindang sering dimanfaatkan untuk kegiatan informan 3 bersama dengan tetangga atau teman. Ruang berkumpul memiliki ruangan yang luas dan pola penataan yang komunikatif sehingga sering digunakan sebagai tempat berinteraksi (perkumpulan RT), ruang ibadah lingkungan, ruang pertemuan dan ruang karoke bersama pada hari jumat.

Informan keempat adalah manula laki-laki berusia 74 tahun tinggal bersama anak, menantu dan cucu. Kondisi fisik informan 4 memiliki cidera kaki sehingga dalam bergerak terbatas dan menggunakan alat bantu berjalan (kruk), kondisi ini berpengaruh terhadap kondisi psikologis sehingga informan 4 menarik diri dari masyarakat, bergantung pada orang lain, terjadi peningkatan sensivitas emosional, untuk mengatasinya manula 4 memiliki kegiatan mengkoleksi tanaman hias dan burung. Kondisi sosial informan 4 tidak mengikuti kegiatan rutin di komplek. Rumah informan 4 terdiri dari 1 lantai dengan 10 ruang didalamnya antara lain teras, ruang tamu, ruang tv, ruang tidur (2), ruang jemur, dapur, ruang makan, dan km/wc(2) (lihat Gambar 4). Ruang preferensi di rumah tinggal informan keempat adalah teras dan ruang tidur. Keterbatasan gerak informan karena cedera membuat informan menghabiskan waktunya di ruang tidur untuk beristirahat dan mendengarkan radio. Teras rumah memiliki ukuran yang cukup besar dan langsung terkena cahaya matahari sehingga dapat menampung koleksi tanaman hias milik informan, selain itu tempat yang nyaman membuat informan betah menikmati koleksi tanaman hias tersebut dan berinteraksi dengan tamu yang datang. 


\section{TEKNIK, 42 (3), 2021, 329}

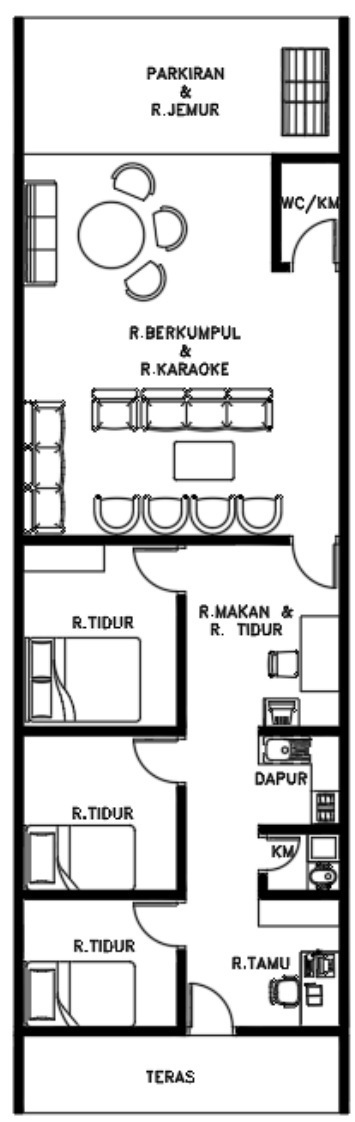

(a)

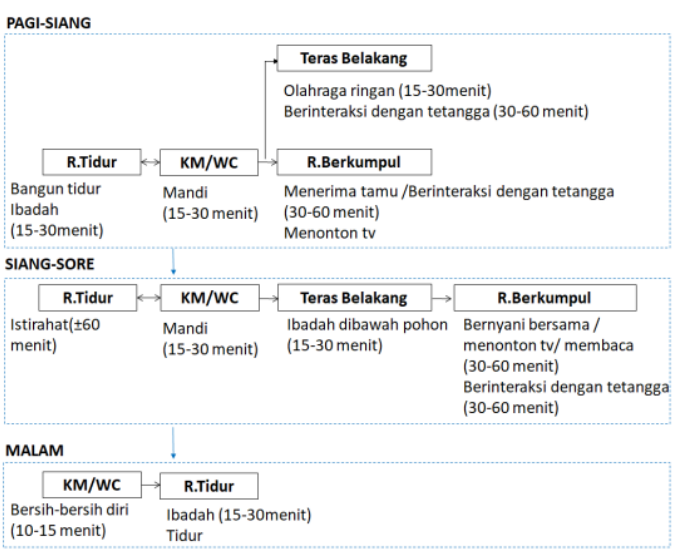

(b)

Gambar 3 (a) Denah rumah informan tiga, (b) Pola aktivitas Informan tiga

Informan kelima, merupakan manula wanita berusia 75 tahun, tinggal dirumah bersama 2 orang anak dan 1 orang cucu. Kondisi kesehatan fisik informan 5 sehat namun berkurangnya kemampuan mata dalam meyesuaikan cahaya dan penyempitan jarak pandang. Kondisi psikologis informan 5 kadang mengingat masa lalu sehingga untuk mengalihkan pikiran informan bermain dengan cucu, memasak, membaca, beribadah dan belajar, sedangkan kondisi sosial informan 5 rutin mengikuti kegiatan keagamaan, olahraga bersama manula, pertemuan PKK, dan suka berinteraksi dengan tetangga. Rumah informan 5 terdiri dari 1 lantai dilengkapi dengan teras, ruang tamu, ruang kerja, ruang keluarga, ruang setrika, ruang tidur (3), ruang makan, dapur(2), gudang(2), dan wc/km (lihat Gambar 5).

Ruang preferensi informan ke lima di rumah tinggal adalah ruang tamu dan ruang tidur informan. Ruang tamu memiliki jendela yang ukurannya cukup besar sehingga cahaya dan udara yang masuk dapat membuat nyaman pengguna sehingga ruangan digunakan informan sebagai tempat berinteraksi dengan tetangga dan bermain dengan cucu. Pada ruang tidur informan menghabiskan waktunya dan terdapat foto-foto lawas sehingga dijadikan tempat nostalgia, selain itu di ruang tidur informan merasa nyaman dan terjaga privasinya.

Informan 6 adalah manula wanita berusia 70 tahun, tinggal bersama anak,menantu dan cucu. Kondisi kesehatan informan 6 sehat dan aktif, sedangkan kondisi sosial tetap rutin mengikuti kegiatan keagamaan, olahraga bersama manula. Rumah tinggal informan 6 terdiri dari 1 lantai yang terdiri dari teras, ruang tamu, ruang tidur (2) dapur, ruang cuci ,km/wc (Gambar 6).

Ruang preferensi informan 6 adalah ruang tamu dan kamar tidur. Ruang tamu sering digunakan informan sebagai tempat untuk berinteraksi dengan keluarganya sedangkan ruang tidur digunakan informan untuk kegiatan pribadi seperti membaca ibadah dan istirahat.

Informan 7, adalah manula pria berusia lebih dari 70 tahun, merupakan ketua RT dan tinggal bersama istri. Kondisi kesehatan fisik manula mudah lelah, dan kondisi sosial informan 7 aktif dalam organisasi masyarakat, aktif mengikuti pengajian dan sering berinteraksi dengan tamu. Rumah informan 7 terdiri dari 1 lantai dengan ruang yang ada didalamnya antara lain teras, ruang tamu, ruang keluarga, ruang tidur(3) dapur, ruang jemur dan $\mathrm{km} / \mathrm{wc}$ (lihat Gambar 7). 


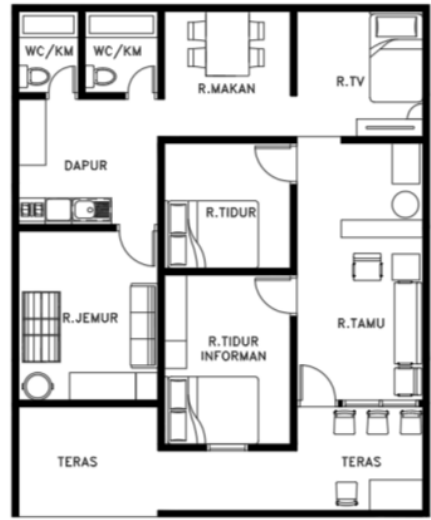

(a)

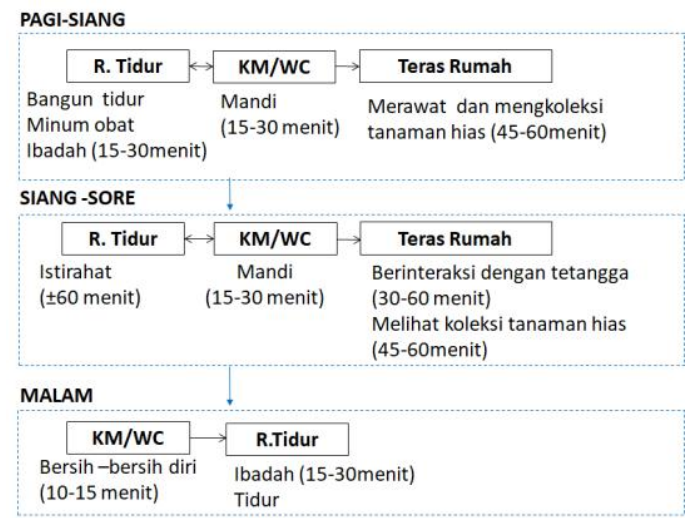

(b)

Gambar 4 (a) Denah rumah informan empat, (b) Pola aktivitas informan empat

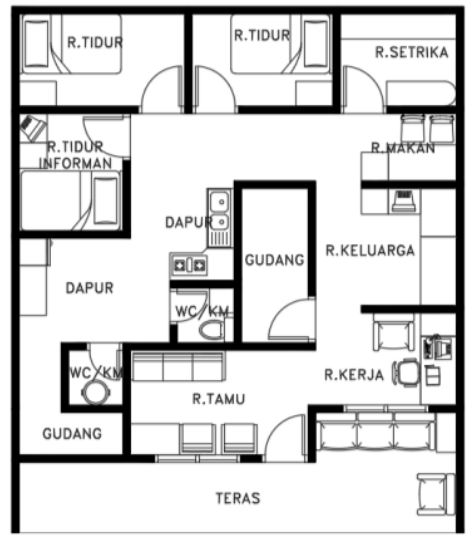

(a)

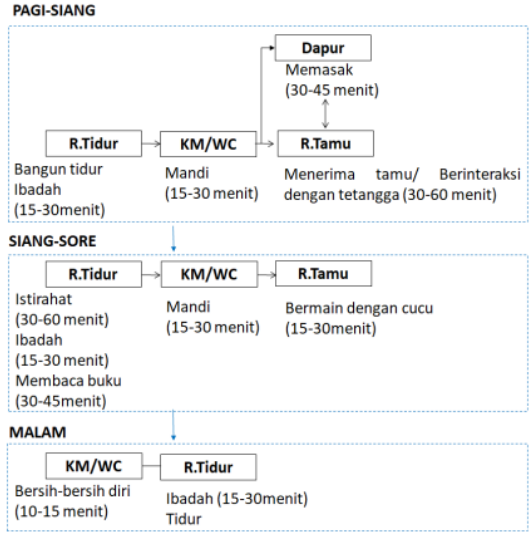

(b)

Gambar 5 (a) Denah rumah informan lima, (b) Pola aktivitas informan lima

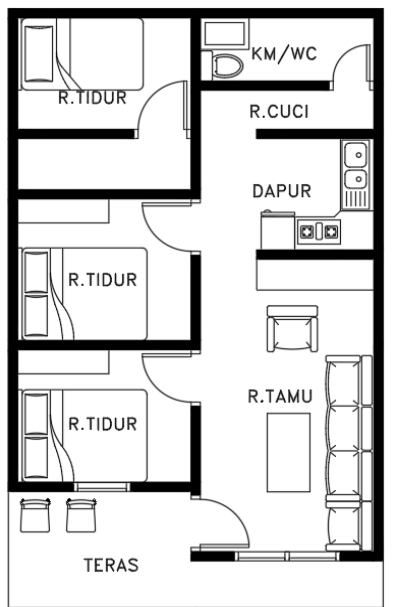

(a)

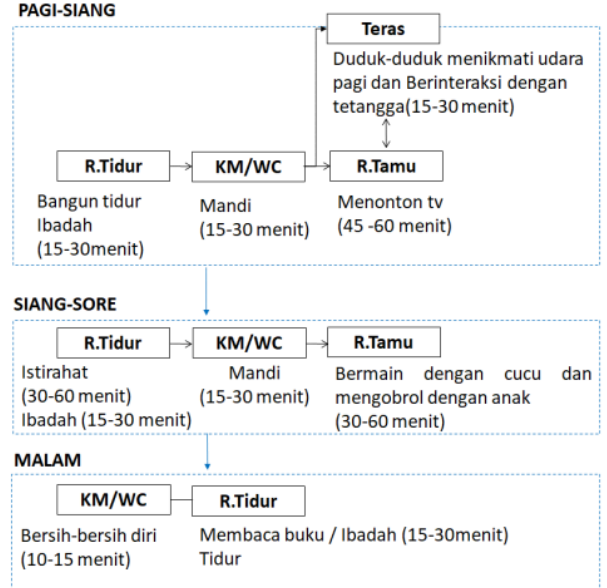

(b)

Gambar 6 (a) Denah rumah informan enam, (b) Pola aktivitas informan enam

Ruang preferensi pada informan 7 adalah teras dan ruang keluarga. Teras didepan rumah terdapat taman kecil dengan tanaman peneduh membuat informan 7 nyaman saat mengobrol dengan tetangga dan sering digunakan informan 7 untuk berinteraksi dengan tetangga maupun tamu sedangkan ruang keluarga sering digunakan informan 7 sebagai tempat menonton tv, makan, dan mengobrol dengan keluarga. 


\section{TEKNIK, 42 (3), 2021, 331}

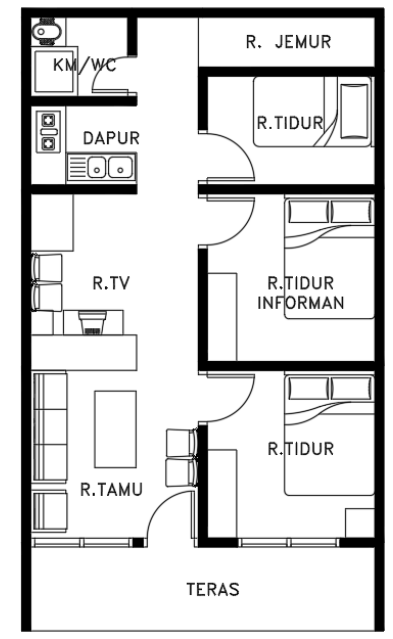

(a)

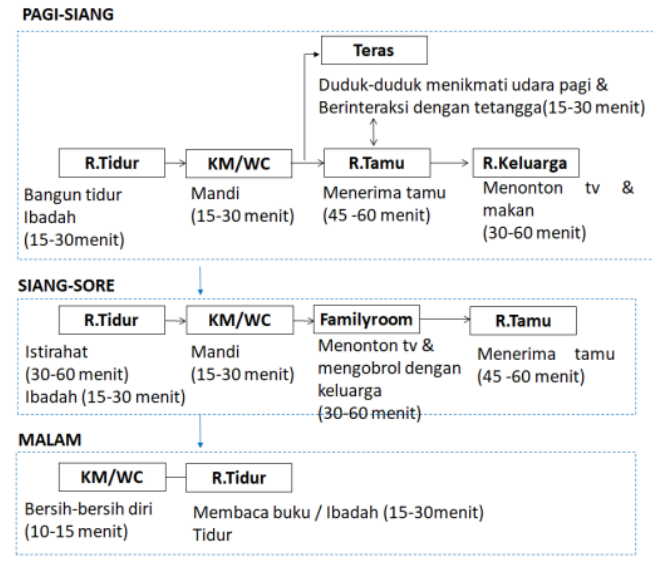

(b)

Gambar 7 (a) Denah rumah informan tujuh, (b) Pola aktivitas informan tujuh

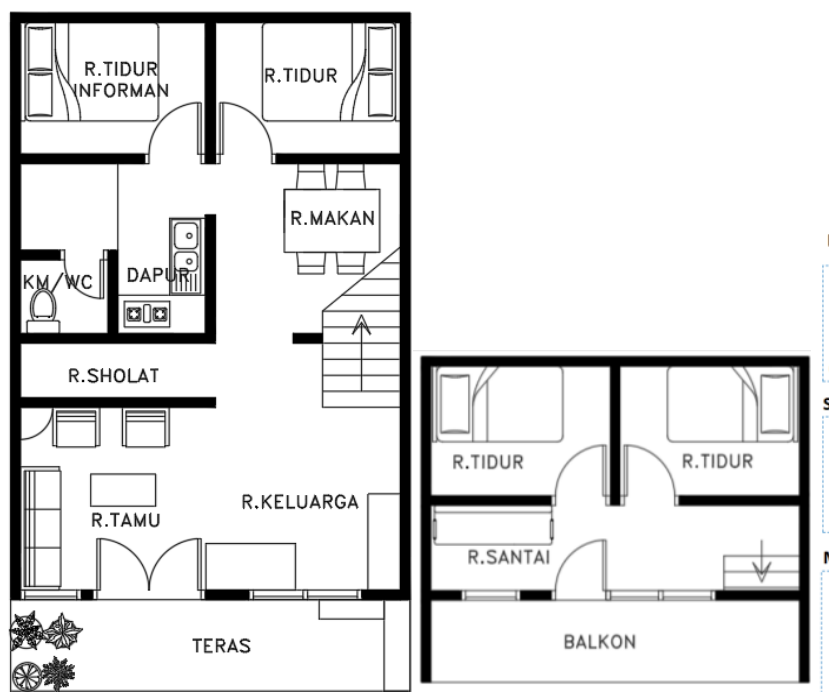

(a)

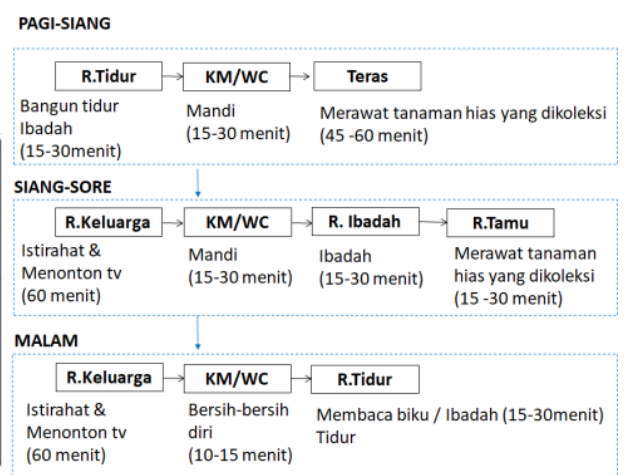

(b)

Gambar 8 (a) Denah rumah informan depalan (lantai 1 dan 2), (b) Pola aktivitas informan delepan

Informan 8 merupakan manula wanita yang berusia 70 tahun dan tinggal seorang. Kondisi fisik informan 8 mudah lelah dikarenakan memiliki riwayat penyakit jantung sehingga aktifitas terbatas, kondisi psikologis informan 8 sering merenungkan kesehatan, dan merasa kesepian untuk mengatasinya manula mengalihkan pikiran dengan mengkoleksi bunga anggrek. Walaupun kondisi kesehatan yang mudah lelah, informan 8 setiap 1 kali dalam seminggu meluangkan waktu mengikuti pengajian, pertemuan masyarakat dan berinteraksi dengan tetangga. Rumah informan 8 terdiri dari 1 lantai dan 6 ruang didalamnya antara lain teras, ruang tamu, ruang sholat, ruang makan, dapur, $\mathrm{km} / \mathrm{wc}$ dan 2 ruang tidur (lihat Gambar 8).

Berkaitan dengan kondisi kesehatan informan 8, ruang preferensi informan 8 adalah teras dan ruang keluarga. Teras yang merupakan ruang terbuka dan mendapatkan cahaya langsung dari matahari digunakan sebagai tempat untuk merawat tanaman hias informan yang telah dikoleksi sejak lama. Sedangan ruang keluarga memiliki ukuran cukup luas dan terdapat bukaan yang cukup lebar sehingga sirkulasi udara sejuk sering dimanfaatkan informan sebagai tempat istirahat, menonton tv dan seminggu sesekali digunakan untuk arisan dan pengajian.

Berdasarkan data diatas ruang preferensi yang dipilih oleh informan pertama sampai dengan 8 terdapat pada Tabel 1. Berdasarkan ruang preferensi dari informan pertama sampai informan 8 terdapat beberapa ruang preferensi manula yang sama namun memiliki fungsi yang berbeda bagi setiap informan, yaitu: Teras secara umum merupakan ruang peralihan dari area luar menuju ruang 


\section{TEKNIK, 42 (3), 2021, 332}

Tabel 1. Ruang preferensi dan kegiatan yang dilakukan informan

\begin{tabular}{|c|c|c|c|c|c|}
\hline \multirow[b]{2}{*}{ Kegiatan } & \multicolumn{5}{|c|}{ Ruang } \\
\hline & & 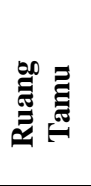 & 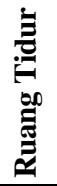 & 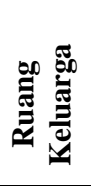 & 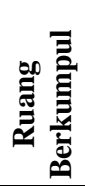 \\
\hline Beribadah pribadi & & $\mathrm{v}$ & $\mathrm{v}$ & & \\
\hline Beribadah bersama & & $\mathrm{v}$ & & $\mathrm{v}$ & $\mathrm{v}$ \\
\hline $\begin{array}{l}\text { Berinteraksi dengan } \\
\text { keluarga }\end{array}$ & & $\mathrm{v}$ & & $\mathrm{v}$ & \\
\hline $\begin{array}{l}\text { Berinteraksi dengan } \\
\text { tetangga / tamu }\end{array}$ & $\mathrm{v}$ & $\mathrm{v}$ & & & \\
\hline Arisan / perkumpulan & & $\mathrm{v}$ & & $\mathrm{v}$ & $\mathrm{v}$ \\
\hline Merawat tanaman & $\mathrm{v}$ & & & & \\
\hline Tidur & & & $\mathrm{v}$ & $\mathrm{v}$ & \\
\hline Membaca & & & $\mathrm{v}$ & & \\
\hline Olahraga pribadi & & & & & \\
\hline $\begin{array}{l}\text { Menonton } \\
\text { tv/mendengarkan radio }\end{array}$ & & & $\mathrm{v}$ & $\mathrm{v}$ & \\
\hline Bermain dengan cucu & & $\mathrm{v}$ & & & \\
\hline Nostalgia foto & & & $\mathrm{v}$ & & \\
\hline
\end{tabular}

dalam rumah atau sebagai ruang penerima tamu dan area tunggu sebelum tamu dipersilahkan masuk kerumah (Hartono, 2019). Ruang teras pada informan 8 difungsikan sebagai tempat untuk menyalurkan hobi mereka seperti merawat tanaman hias atau hewan peliharaan, terlihat bahwa teras memiliki makna ruang personal bagi informan tersebut. Hal ini berbeda dengan informan 3, informan 4 dan informan 7, mereka menggunakan sebagai ruang interaksi dengan tetangga. Namun teras juga dimaknai sebagai ruang personal dan ruang interaksi bagi informan satu.

Ruang tamu merupakan ruang khusus sebagai tempat menerima tamu (Hartono, 2019). Ruang tamu pada informan 5 dan informan 6 dimaknai sebagai tempat untuk berinteraksi dengan tamu atau tetangga perumahan yang datang untuk mengobrol, terlihat bahwa ruang tamu memiliki makna sebagai ruang interaksi bagi informan tersebut. Informan kedua tidak hanya memaknai ruang tamu sebagai ruang interaksi tetapi juga sebagai ruang ibadah. Namun informan pertama tidak menggunakan sebagai ruang interaksi namun sebagai ruang personal dan ruang ibadah.

Ruang keluarga merupakan salah satu ruang di rumah yang digunakan untuk ruang bertemu anggota keluarga (Kusyanto \& Kusuma, 2015). Hal ini juga terlihat pada informan satu yang memaknai ruang keluarga sebagai ruang interaksi. Namun informan 8 tidak hanya memaknai ruang keluarga sebagai ruang interaksi tetapi juga sebagai ruang ibadah dan ruang personal.

Ruang tidur merupakan ruang yang digunakan untuk aktivitas tidur dan istirahat manula (Sirnani et al.,
Tabel 2. Kategori ruang manula

\begin{tabular}{|c|c|c|c|c|}
\hline \multirow[b]{2}{*}{ Informan } & \multirow[b]{2}{*}{$\begin{array}{c}\text { Ruang } \\
\text { Preferensi }\end{array}$} & \multicolumn{3}{|c|}{ Kategori Ruang } \\
\hline & & 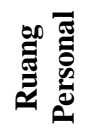 & 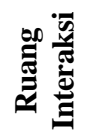 & 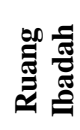 \\
\hline \multirow{2}{*}{1} & Ruang Tamu & $\mathrm{v}$ & & $\mathrm{v}$ \\
\hline & Teras & $\mathrm{v}$ & $\mathrm{v}$ & \\
\hline \multirow{2}{*}{2} & Ruang Tamu & & $\mathrm{v}$ & $\mathrm{v}$ \\
\hline & Ruang Tidur & $\mathrm{v}$ & & $\mathrm{v}$ \\
\hline \multirow{2}{*}{3} & Teras & & $\mathrm{v}$ & \\
\hline & R.Berkumpul & & $\mathrm{v}$ & $\mathrm{v}$ \\
\hline \multirow{2}{*}{4} & Teras & $\mathrm{v}$ & $\mathrm{v}$ & \\
\hline & Ruang Tidur & $\mathrm{v}$ & & \\
\hline \multirow{2}{*}{5} & Ruang Tamu & & $\mathrm{V}$ & \\
\hline & Ruang Tidur & $\mathrm{v}$ & & $\mathrm{v}$ \\
\hline \multirow{2}{*}{6} & Ruang Tamu & & $\mathrm{v}$ & \\
\hline & Ruang Tidur & $\mathrm{v}$ & & $\mathrm{v}$ \\
\hline \multirow{2}{*}{7} & Teras & & $\mathrm{v}$ & \\
\hline & R.Keluarga & & $\mathrm{v}$ & \\
\hline \multirow{2}{*}{8} & Teras & $\mathrm{v}$ & & \\
\hline & R.Keluarga & $\mathrm{v}$ & $\mathrm{v}$ & $\mathrm{v}$ \\
\hline
\end{tabular}

2016). Hal ini juga terlihat pada informan 4 yang memaknai ruang tidur sebagai ruang personal. Namun pada informan kedua, informan 5, dan informan 6, ruang tidur tidak hanya sebagai ruang personal tetapi juga sebagai ruang ibadah.

\section{Kategori Ruang Preferensi Manula}

Berdasarkan analisa diatas maka kategori ruang preferensi manula di Perumnas Banyumanik adalah pertama ruang personal, yaitu ruang pribadi yang didefinisikan menurut proses di mana orang menandai dan mempersonalisasi ruang yang mereka huni, termasuk ruang sosial umum (Sommer, 1969). Kedua ruang interaksi, yaitu ruangan tanpa batas atau penyekat yang berfungsi sebagai ruang interaksi sesama penghuni maupun pemukim di lingkungannya (Mulyati, 2008). Ketiga ruang ibadah, yaitu area privat dan tenang yang digunakan untuk penghuni beribadah (Sastra, 2015). Ketiga kategori ruang preferensi manula tersebut secara sederhana dapat dilihat pada Tabel 2.

Terlihat pada Tabel 2 bahwa pada beberapa informan terdapat 2 kategori dalam satu ruang preferensi hal tersebut dikarenakan informan memiliki kondisi kesehatan yang berbeda satu sama lain sehingga manula cenderung menggabungkan beberapa aktivitas dalam satu ruang, seperti ruang tamu dimaknai sebagai ruang interaksi dan ruang ibadah. Hal ini dipengaruhi oleh atribut manula yang membentuk sebuah ruang berdasarkan aspek sosial dan spiritual (Wijayanti et al., 2018).

Berdasarkan 3 kategori ruang preferensi manula diatas terdapat 2 orientasi di masing-masing kategori ruang yaitu orientasi internal dan eksternal antara lain: 


\section{TEKNIK, 42 (3), 2021, 333}

\section{a. Ruang Personal}

Ruang personal berorientasi internal merupakan ruang dimana manula mempersonalisasi ruang pada ruang yang lebih tertutup dan bersifat lebih privat, dimana manula dapat memiliki waktu untuk istirahat dan menghibur diri dengan mendengarkan lagu, menikmati foto-foto kenangan atau foto-foto nak dan cucu yang disimpan dalam album maupun yang dipajang di dinding kamar tidur.

Ruang personal yang bersifat eksternal merupakan ruang dimana manula memperoleh kesenangan maupun kedamaian diri dari apa yang didengar, dilihat dan dirasakan dari sumber-sumber yang berasal dari luar rumah manula dapat berupa pemandangan alam di sekitar rumah, keramaian lalu lalang orang di depan rumah, suara adzan, lampu-lampu yang menyinari lambang "Allah" di atas masjid, semilir angin. Letak ruang dapat berada di bagian dalam rumah maupun di bagian luar, seperti halnya teras di depan rumah atau balkon di lantai dua.

Dari kedua bahasan terkait dengan ruang personal di atas, pemahaman ruang personal ini berbeda dengan apa yang disampaikan oleh Elias \& Cook yang melakukan studi di Reena Community Residence (RCR), sebuah model perumahan inovatif untuk campuran komunitas manula dengan berbagai kebutuhan khusus, yang mana ruang personal yang dimaksud adalah ruang yang menunjukkan personalisasi manula secara individu dan dapat berada di ruang yang lebih terbuka dan bersifat umum (Elias \& Cook, 2016). Ruang personal baik yang berorientasi internal dan eksternal pada studi ini, merujuk pada ruang yang lebih bersifat tertutup dan privat namun keduanya memiliki peran dalam memberikan kesempatan mamula memperoleh pengalaman fisik dan non fisik dari berbagai sumber dan elemen yang ada di dalam ruang maupun yang ada di luar ruang.

\section{b. Ruang interkasi}

Ruang Interaksi terdiri dari 2 orientasi yaitu internal dan sosial eksternal. Ruang interkasi internal merupakan ruang dimana interaksi sosial bersifat lebih privat dan terjadi dalam internal keluarga manula terutama pada manula yang tinggal bersama anak-menantu dan cucu. Ruang ini adalah ruang keluarga. Ruang interaksi sosial eksternal merupakan ruang dimana manula bisa melakukan interasi secara langsung dengan orang-orang di luar rumah manula. Interkasi tersebut dapat terjadi secara mendalam dalam sebuah kegiatan "ngobrol" dengan satu atau lebih orang yang biasanya sudah akrab seperti tetangga di sekitar rumah manula, atau interaksi yang terjadi sesaat atau hanya saling menyapa antar manula dan teman atau tetangga. Ruang interkasi sosial eksternal ini adalah teras yang terletak di depan rumah dan langsung berhadapan dengan jalan. Manula mendapatkan kesempatan interaksi sosial ini pada waktu pagi, siang dan sore hari. Kesempatan tersebut diperoleh karena jarak yang dekat antar teras dan jalan, dan jalan yang memang didesain sejak awal sebagai jalan yang hanya bisa dilalui oleh pejalan kaki dan kendaraan roda 2. Dengan kesempatan bisa beriteraksi sosial eksternal ini manula mendapatkan kebahagian karena merasakan adanya kehangatan karena hubungan kekeluarga yang sudah terjalin sejak awal mereka tinggal di perumahan. Manula masih merasa ada orang lain yang dekat dengannya terlebih bagi manula yang tinggal sendiri seperti halnya informan pertama, ruang interaksi sosial eksternal ini juga menjadi ruang yang penting bagi manula yang memiliki keterbatasan gerak sehingga tidak leluasa untuk berjalan sendiri untuk keluar rumah bertemu dengan teman atau tetangga di sekitar rumahhnya, seperti halnya informan 4 , ruang ini diandalkan manula sebagai ruang yang bisa memberikan kesempatan untuk bertemu dengan teman atau tetangga atau bahkan hanya tempat untuk melihat lalu lalangnya orang di depan rumah.

Uraian di atas menunjukkan secara fisik ruang preferensi manula yang dapat membuka peluang manula dapat terkoneksi secara sosial baik dengan keluarga dalam satu rumah maupun dengan orang-orang yang berada di luar rumah. Baik ruang preferensi yang berorientasi internal maupun eksternal diwujudkan dalam fungsi ruang dan letaknya secara fisik, dalam tatanan ruang-ruang di dalam rumah. Dengan perkembangan teknologi kecerdasan buatan (artificial intelligence), maka ruang interaksi dapat saja bergerak (mobile), tidak merunjuk pada sebuah ruang yang jelas fungsi dan bentukan fisiknya, sehingga secara virtual manula dapat melakukan kontak sosial baik dengan keluarga maupun dengan orangorang di luar rumah (Blom et al., 2016). Namun demikian terlepas dari teknis apapun terkait dengan bagaimana manula menjalin kontak sosial, terdapat hal penting yang patut digaris bawahi terkait dengan adanya perwujudan sistem hubungan sosial pada manula yang dapat dijadikan sebagai dasar bagi pengembangan hunian yang dapat mengakomodasi kehidupan manula (Li et al., 2020).

\section{c. Ruang ibadah}

Ruang ibadah internal adalah ruang manula bersifat privat, dimana hanya manula yang menggunakan untuk beribadah ke Tuhannya. Bagi manula yang tinggal bersama dengan anak-menantu dan cucu, ruang ibadah yang bersifat privat dilakukan di ruang tidur manula. Di ruang ini manula dapat mengatur ruang sesuai dengan kegiatan ibadah yang dilakukan. Beberapa atribut yang diperlukan ibadah mempengaruhi tata letak perabot yang disesuaikan dengan kemudahan manula menjangkau atau menggunakan atribut yang diperlukan. Hal ini seperti yang dilakukan informan kedua, yang menggunakan ruang tidurnya sebagai ruang istirahat sekaligus sebagai ruang ibadah. Bagi informan 8 yang tinggal sendiri, ruang ibadah privat berada di ruang keluarga, dimana atribut ibadah memiliki tempat yang sengaja disiapkan untuk ibadah.

Ruang ibadah eksternal, merupakan ruang yang digunakan manula untuk beribadah bersama dengan 


\section{TEKNIK, 42 (3), 2021, 334}

komunitasnya. Ruang ini digunakan secara berkala dan rutin. Ruang ini penting bagi manula karena menyangkut ibadah sebagai kebutuhan manula dalam mengisi waktunya. Ruang yang digunakan adalah ruang tamu atau kelauraga yang bersifat terbuka dan mudah diatur sesuai dengan kebutuhan kegitan yang ada.

Keberadaan ruang ibadah sebagai ruang preferensi manula memberikan pemahaman pentingnya ibadah bagi manula. Ibadah merupakan aktivitas yang menunjukkan hubungan seseorang dengan Tuhannya dalam kerangka keyakinan agama yang dianutnya. Dalam sistem perawatan kesehatan, pendekatan keyakinan agama tersebut akan membantu seseorang dalam pemulihan kesehatan (Rumun, 2014). Dengan demikian dengan adanya ruang ibadah sebagai ruang peferensi manula, menunjukkan pentingnya ibadah bagi manula dan perlunya ruang-ruang yang sesuai dengan ibadah yang dijalaninya. Harapannya manula akan memperoleh manfaat dari aktivitas ibadah yang dilakukan.

\section{Kesimpulan}

Hasil penelitian menunjukkan adanya 3 kategori ruang preferensi untuk orang tua yang berusia lanjut/ manula yaitu ruang personal, ruang interaksi dan ruang ibadah. Hasil terebut diharapkan dapat memberikan wawasan serta panduan bagi proses perencanaan dan peracangan rumah yang ramah bagi manula, dalam rangka memberikan kesempatan penghuninya dapat menghabiskan masa tuanya di rumahnya dengan nyaman.

\section{Daftar Pustaka}

Aung, M. N., Koyanagi, Y., Ueno, S., Tiraphat, S., \& Yuasa, M. (2021). A Contemporary Insight into an Age-Friendly Environment Contributing to the Social Network, Active Ageing and Quality of Life of Community Resident Seniors in Japan. Journal of Aging and Environment, 35(2), 145-160.

Blom, J., French, T., \& Teal, G. (2016). Interaction Space: Older Adults and in-Home Systems.

Ekasari, M. F., Riasmini, N. M., \& Hartini, T. (2019). Meningkatkan Kualitas Hidup Lansia Konsep dan Berbagai Intervensi. Wineka Media.

Elias, B. M., \& Cook, S. L. (2016). Exploring the connection between personal space and social participation. Journal of Housing for the Elderly, 30(1), 107-122.

Hartono, W. (2019). Transformasi ruang pada rumah tinggal penggiat komunitas reog di Pendukuhan Gunungsari Desa Bejiharjo, Kabupaten Gunungkidul. ARTEKS: Jurnal Teknik Arsitektur, 4(1), 13-24.

Howden-Chapman, P., Signal, L., \& Crane, J. (1999). Housing and health in older people: ageing in place.
Social Policy Journal of New Zealand, 14-30.

Kusyanto, M., \& Kusuma, H. E. (2015). Ruang Keluarga yang Ideal. 1, 177-180.

Li, C., Kang, K., Lin, X., Hu, J., Hengeveld, B., \& Hummels, C. (2020). Promoting older residents' social interaction and wellbeing: a design perspective. Sustainability, 12(7), 2834.

Luciano, A., Pascale, F., Polverino, F., \& Pooley, A. (2020). Measuring age-friendly housing: A framework. Sustainability, 12(3), 848.

Mendoko, F., Katuuk, M., \& Rompas, S. (2017). Perbedaan Status Psikososial Lanjut Usia Yang Tinggal Di Panti Werdha Damai Ranomuut Manado Dengan Yang Tinggal Bersama Keluarga Di Desa Sarongsong II Kecamatan Airmadidi Kabuaten Minahasa Utara. JURNAL KEPERAWATAN, 5(1).

Mulyati, A. (2008). Kajian luas rumah tinggal masyarakat berpenghasilan rendah di kawasan pusat kota. SMARTek, 6(3).

Nova, M. (2013). Preferensi Manula terhadap Jenis Lampu, Warna Suhu Lampu dan Warna Dinding pada Ruang Tidur Kasus Studi Panti Wreda Hanna Yogyakarta. Tesis.[serial online]. http://e-journal. uajy. ac. id/4230/3/2MTA01687. pdf ....

Omiya, Y., Suzumura, S., Itoh, N., Osawa, A., Tateno, R., Mizuno, A., \& Kondo, I. (2016). Effect of adaptations to the living environment on ADL abilities and self-perception of performance/satisfaction-Based on experience from post-discharge home visits-. Japanese Journal of Comprehensive Rehabilitation Science, 7 , 95-101.

Prosper, V. (2004). Aging in place in multifamily housing. Cityscape, 81-106.

Rumun, A. J. (2014). Influence of religious beliefs on healthcare practice. Int J Educ Res, 2(4), 37-48.

Sastra, S. (2015). Inspirasi Desain Hunian Modern. Elex Media Komputindo.

Sirnani, D. T., Handajani, R. P., \& Astrini, W. (2016). Ruang Dalam Rumah Tinggal Lansia Di Kota Malang dengan Pendekatan Kemunduran Motorik Studi Kasus Nyeri Lutut dan Nyeri Punggung Bawah. Jurnal Mahasiswa Jurusan Arsitektur, 4(4).

Sommer, R. (1969). Personal Space. The Behavioral Basis of Design.

Triyuly, W., \& Kusuma, H. E. (2015). Ruang Favorit dalam Rumah. 1.

Wijayanti, Soetomo, S., \& Pandelaki, E. E. (2018). Housing Adaptation in Public Housing by The Elderly Case Study: Banyumanik Public Housing in Semarang City, Indonesia. 8(2), 182-195.

Wiles, J. L., Leibing, A., Guberman, N., Reeve, J., \& Allen, R. E. S. (2012). The meaning of "aging in place" to older people. The Gerontologist, 52(3), 357-366. 